\title{
A new species of Tunga perforating the osteoderms of its armadillo host in Argentina and redescription of the male of Tunga terasma
}

\author{
M. C. EZ QUIAGA ${ }^{1}$, P. M. L INAR DI ${ }^{2}$, D. M. DEAVELAR ${ }^{3}$ and \\ M. L A R E S C H I ${ }^{1,4}$ \\ ${ }^{1}$ Centro de Estudios Parasitológicos y de Vectores (CEPAVE) (CCT La Plata-CONICET-UNLP), La Plata, Argentina, \\ ${ }^{2}$ Departamento de Parasitologia, Instituto de Ciências Biológicas, Universidade Federal de Minas Gerais, Belo Horizonte, MG, \\ Brazil, ${ }^{3}$ Laboratório de Pesquisas Clínicas, Centro de Pesquisas René Rachou, Fundação Oswaldo Cruz, Belo Horizonte, MG, Brazil \\ and ${ }^{4}$ Cátedra Zoología General, Facultad de Ciencias Naturales y Museo, Universidad Nacional de La Plata, La Plata, Argentina
}

\begin{abstract}
A new species of Tunga (Siphonaptera: Tungidae) collected from armadillos in Argentina is described. The new species is characterized by large and pigmented eyes, the presence of two bristles on antennal segment II, two bristles at the base of the maxilla, and a discoid neosome compressed anteroposteriorly. The gravid female is located in the carapace of the host, perforating the osteoderms. The new species resembles Tunga penetrans and Tunga terasma in general appearance. However, it differs by the greater anteroposterior compression of the neosome, a more angular head, and a manubrium with a pointed proximal end and convex ventral margin (the proximal end of the manubrium is rounded or slightly pointed in T. terasma, and the ventral margin is straight in both $T$. penetrans and T. terasma). In addition, specimens of $T$. penetrans have more bristles in antennal segments II and III, and lack bristles in the posterior tibia. This is the first report of a species of Tunga perforating the osteoderms of its host and thereby showing a high degree of specialization. Tunga terasma is recorded for the first time in Argentina; the male is described again and the characteristics of the species amended. This information may be useful in epidemiological studies of diseases caused by species of Tunga.
\end{abstract}

Key words. Chaetophractus vellerosus, Zaedyus pichiy, Dasypodidae, Siphonaptera.

\section{Introduction}

Armadillos (Cingulata), anteaters and sloths (Pilosa) constitute the Xenarthra, a characteristic and exclusive group from the Neotropical region (Delsuc et al., 2002). Armadillos are parasitized by several species of flea, most of which belong to the families Malacopsyllidae (Smit, 1987) and Tungidae (Hopkins \& Rothschild, 1953). Fleas of the genus Tunga Jarocki, 1838 (Tungidae) are distinguished by the fact that females penetrate while males move over the body of the host. Non-gravid females dig into the epidermis of the host and, once in place in it, with their head toward the deepest part of the integument and their abdomen out, are fertilized by males from the outside (Marshall,
1981). The abdomen of fertilized females increases to up to 10 times its original size. This morphological change, designated 'neosomy' by Audy et al. (1972), causes a compressive effect that results in a cavity in the skin of the host (Pampiglione et al., 2009).

The genus Tunga includes 13 species of flea distributed around the tropics (De Avelar etal., 2013). Smit (1962) divided the genus into two groups, the 'penetrans group' and the 'caecata group'. The penetrans group is characterized by the dorsal fusing of the pronotum with the mesonotum, a reduction in the chaetotaxy of tarsal segment $V$, the presence of two lateral pairs of plantar bristles and the absence of grouping of small plantar bristles. At present this group includes Tunga penetrans

\footnotetext{
Correspondence: María C. Ezquiaga, Centro de Estudios Parasitológicos y de Vectores (CEPAVE) (CCT La Plata-CONICET-UNLP), Calle 120 s/n entre 60 y 64, La Plata B1906CXR, Argentina. Tel.: + 54221423 2324; Fax: + 542214232324 (ext. 12); E-mail: cecilia@ cepave.edu.ar
} 
(L., 1758), Tunga bondari Wagner, 1932, Tunga travassosi Pinto \& Dreyfus, 1927, Tunga terasma Jordan, 1937, Tunga trimamillata Pampiglione, Trentini, Fioravanti, Onore \& Rivasi, 2002, and Tunga hexalobulata De Avelar, Facury Filho \& Linardi, 2013.

In species of the caecata group, the pronotum is not fused with the mesonotum, the chaetotaxy of tarsal segment $\mathrm{V}$ is not reduced, and three or four lateral pairs of plantar bristles and a grouping of small plantar bristles are present. Included in this group are Tunga caecata Enderlein, 1901, Tunga caecigena Jordan \& Rothschild, 1921, Tunga callida Li \& Chin, 1957, Tunga libis Smit, 1962, Tunga monositus Barnes \& Radovsky, 1969, Tunga bossii de Avelar, Linhares \& Linardi, 2012, and Tumga bonneti Beaucournu \& González-Acuña, 2012. Only T. penetrans and T. trimamillata parasitize humans and domestic animals. Recently, a relatively new species from Brazil, T. hexalobulata, was described as also parasitizing bovines (De Avelar et al., 2013). These fleas cause tungiasis, a disease that manifests in skin disorders that may result in severe complications such as the deformation of digits and loss of toenails, tetanus and gangrene (González et al., 2003; Heukelbach et al., 2004; Lareschi et al., 2005). The remaining species are parasites of wild mammals, most of which are rodents and xenarthrans (Linardi \& Guimarães, 2000; Whiting et al., 2008; Pampiglione et al., 2009; De Avelar, 2010). A recent review of the neosomes of tungid species (Linardi \& De Avelar, 2014) described their morphology, taxonomy, geographical distribution, hosts, prevalence, sites of attachment and impact on wild and domestic animals, as well as perspectives for future studies concerning the possibility of the discovery of other species of sand flea and their adaptation to new hosts.

At present, in Argentina, only T. penetrans has been recorded as parasitizing humans, domestic animals and a few species of dasypodids, including Chaetophractus villosus (Desmarest, 1804), Chaetophractus vellerosus (Gray, 1865) and Dasypus hybridus (Desmarest, 1804) (all: Cingulata: Dasypodidae) (González etal., 2003; Lareschi etal., 2005; Ezquiaga etal., 2008; Ezquiaga, 2013). Herein, we describe a new species of Tunga identified in Argentina. This new species has been recovered from armadillos and its gravid females are unique in their perforation of the osteoderms of hosts. Moreover, T. terasma is identified for the first time in Argentina; the male of the species is redescribed and its characteristics amended. Thus, the redescription provided herein, as well as the amended identification key, are important to the identification of this species and to distinguishing it from similar species that occur in the same localities or hosts.

\section{Materials and methods}

Male and non-gravid female fleas were collected by examining armadillos. Specimens were stored in $96 \%$ ethanol, cleared in $10 \%$ potassium hydroxide, dehydrated in an increasing series of ethanol ( $80-100 \%)$, diaphonized in eugenol and mounted in Canadian balsam for the purposes of the study. Gravid females were removed from osteoderms using pins and photographed under a stereoscopic microscope. Drawings and photographs were made using an Olympus BX51 microscope (Olympus
Corp., Tokyo, Japan) equipped with a drawing tube and photographic camera. Measurements are given in micrometres $(\mu \mathrm{m})$ unless otherwise stated, as mean values followed by range values in parentheses, followed by the number of specimens measured $(n)$. Fleas were deposited in the Colección de Entomología Museo de La Plata (MLP), La Plata, Buenos Aires, Argentina. At present, fleas hold a field number. Original descriptions were used for identifying the species. For comparative purposes, specimens of T.penetrans and T.terasma deposited in the collections of the Departamento de Parasitologia, Instituto de Ciencias Biológicas, Universidade Federal de Minas Gerais (Department of Parasitology, Institute of Biological Sciences, Federal University of Minas Gerais), Brazil, and the Museu de Zoologia da Universidade de São Paulo (Zoological Museum of the University of São Paulo), São Paulo, Brazil were examined by two of the authors (PML and DMdA).

\section{Results}

Tunga perforans $n . s p$.

Type specimens. Ex Zaedyus pichiy (Cingulata: Dasypodidae), Cabo Raso, Chubut Province: holotype male (MLP-XNT17, M1) (30 January 2009); paratypes: ex Z. pichiy, Cabo Raso, Chubut Province: one male (MLP-XNT17, M2) (30 January 2009); ex Z. pichiy, Luján de Cuyo, Mendoza Province $\left(33^{\circ} 01^{\prime} \mathrm{S}, 68^{\circ} 55^{\prime} \mathrm{W}\right)$ (22 February 2009): nine males (MLP-ZP312, M1-M9) and two non-gravid females (MLP-ZP312, F1, F2); ex C.vellerosus, Usno, San Juan Province $\left(30^{\circ} 33^{\prime} 39^{\prime \prime} \mathrm{S}, 67^{\circ} 32^{\prime} 15^{\prime \prime} \mathrm{W}\right)$ : one neosome in ethanol (MLP-SJ030).

Additional specimens studied. La Madrugada, Chubut Province $\left(43^{\circ} 37^{\prime} 40^{\prime \prime} \mathrm{S}, \quad 68^{\circ} 57^{\prime} 08^{\prime \prime} \mathrm{W}\right)$, two males (MLP-XNT10, M1, M2).

Type host. Zaedyus pichiy (Desmarest, 1804) (XNT17) captured, identified and released in the field.

Other host. Chaetophractus vellerosus (Gray, 1865).

Type locality. Cabo Raso, Chubut Province $\left(44^{\circ} 20^{\prime} 22^{\prime \prime} \mathrm{S}\right.$, $65^{\circ} 14^{\prime} 59^{\prime \prime} \mathrm{W}$ ).

Other localities. Luján de Cuyo, Mendoza Province (33 $\left.01^{\prime} \mathrm{S}, 68^{\circ} 55^{\prime} \mathrm{W}\right)$; La Madrugada, Chubut Province $\left(43^{\circ} 37^{\prime} 40^{\prime \prime} \mathrm{S}, \quad 68^{\circ} 57^{\prime} 08^{\prime \prime} \mathrm{W}\right)$; Usno, San Juan Province $\left(30^{\circ} 33^{\prime} 39^{\prime \prime} \mathrm{S}, 67^{\circ} 32^{\prime} 15^{\prime \prime} \mathrm{W}\right)$; 22 September 2011.

Diagnosis. Tunga perforans $\mathrm{n}$. sp. belongs to the penetrans group because its pronotum is fused dorsally with the mesonotum, the chaetotaxy of tarsal segment $\mathrm{V}$ is reduced and two lateral pairs of plantar bristles are present (Smit, 1962; Linardi 
\& Guimarães, 2000). The new species described here possesses internal preoral sclerotization similar to that in T. bondari, but differs by having two bristles in antennal segment II ( $T$. bondari has only one), one to three bristles in females, and three placoids in segment III (absent in T.bondari), and larger eyes $(52 \times 27 \mu \mathrm{m}$ in $T$. bondari). In addition, T. perforans $\mathrm{n}$. $\mathrm{sp}$. differs from T. travassosi in having larger and pigmented eyes (eyes are smaller and without pigment in T.travassosi). The new species is similar to T. terasma and T.penetrans in general appearance, but differs by its larger anteroposterior compression and smaller size of the neosome, more angular head and the presence of two bristles at the base of the maxilla. Males can be differentiated by the shape and chaetotaxy of segment IX. In the new species, the manubrium is pointed at the proximal end and the ventral margin is convex (the proximal end of the manubrium is rounded or slightly pointed in T. terasma, and the ventral margin is straight in T. penetrans and T.terasma). In T.perforans $\mathrm{n}$. sp., the telomere is wider than the basimere at the median part, whereas the opposite is true in T. terasma. Further, the basimere of the new species is devoid of bristles at the apical part, whereas in T. terasma it presents three apical bristles. In T. perforans n. sp., both parts of the phallosome are equal in size and the angle between them is acute, whereas in T.terasma the proximal part is slightly longer than the distal part, and the angle between them is slightly more obtuse. Moreover, specimens of $T$. penetrans have more bristles on antennal segment III, lack bristles in the posterior tibia and have a greater number of bristles on antennal segment II.

Description. Fleas are small [males: $863 \pm 99 \mu \mathrm{m}$ $(758-1030 \mu \mathrm{m})(n=13)$; females: $720 \pm 81 \mu \mathrm{m}(662-778 \mu \mathrm{m})$ $(n=2)]$. Head: dorsal margin with five bristles, posterior to the frontal tubercle. In the preoral internal sclerotization, the posterior arm [33 $\pm 10 \mu \mathrm{m}(25-55 \mu \mathrm{m}) ; n=13]$ is slightly longer than the anterior arm $[24 \pm 4 \mu \mathrm{m}(21-33 \mu \mathrm{m}) ; n=13]$ in males, and nearly twice as long $[46 \pm 3 \mu \mathrm{m}(43-48 \mu \mathrm{m})(n=2)$ and $28 \pm 5 \mu \mathrm{m}(24-31 \mu \mathrm{m})(n=2)$, respectively] in females. The eye is large and pigmented, measuring $46 \pm 3 \mu \mathrm{m}(42-55 \mu \mathrm{m})$ by $38 \pm 3 \mu \mathrm{m}(34-45 \mu \mathrm{m})(n=13)$ with a sinus in the internal margin; its smaller diameter is similar to the shortest distance between the eye and the dorsal margin of the head $[40 \pm 8 \mu \mathrm{m}$ $(31-58 \mu \mathrm{m}) ; n=13]$ (Fig. 1A). The genal process extends to the antennal fossa and covers part of antennal segment III. Antennal segment II has two bristles (Fig. 1B). Antennal segment III has six sensorial organs and three placoids, without bristles in males, and with one to three bristles in females. The laciniae are heavily serrated and slightly longer $[281 \pm 16 \mu \mathrm{m}$ $(264-310 \mu \mathrm{m}) ; n=13]$ than the maxillary palps $[232 \pm 17 \mu \mathrm{m}$ (204-263 $\mu \mathrm{m}) ; n=13]$. The maxillary palps have few bristles (Fig. 1C). Segments I, II and IV of the maxillary palps are roughly equal in size, whereas segment III measures slightly more than half of the others: segment I: $62 \pm 4 \mu \mathrm{m}(56-70 \mu \mathrm{m})$; segment II: $64 \pm 7 \mu \mathrm{m}(52-75 \mu \mathrm{m})$; segment III: $38 \pm 6 \mu \mathrm{m}$ $(23-47 \mu \mathrm{m})$, and segment IV: $68 \pm 4 \mu \mathrm{m}(62-76 \mu \mathrm{m})(n=13)$. The base of the maxilla has two bristles.

Thorax: the pronotum is fused dorsally to the mesonotum. There are three bristles on the pronotum and two on the mesonotum. The proepimeron has a pointed posterodorsal lobe (Fig. 1D).

Legs: the procoxa $[195 \pm 11 \mu \mathrm{m}(168-209 \mu \mathrm{m}) ; n=12]$ measures two-thirds of the laciniae, with 13 bristles; the trochanter has two anterior bristles; the femur has nine or 10 posterior bristles, and the tibia has three large and five small posterior bristles. The mesocoxa has eight or nine bristles, the trochanter six to nine bristles, and the femur six to 11 posterior bristles. The metacoxa shows eight or nine anterior bristles on the external side, and six to 10 thin bristles on the internal side (restricted to the anterior margin) (Fig. 1E). The trochanter has two bristles, the femur has two rows of bristles, four in the anterior row and five in the posterior row, and the metatibia has four bristles in the anterior margin (unknown in females) (Fig. 1F).

Abdomen of the male: the respiratory spiracles are flower-shaped; all spiracles are of similar size. Segment IX presents the manubrium with an almost straight dorsal margin and a convex ventral margin, and a sharp proximal end, measuring $174 \pm 15 \mu \mathrm{m}(150-200 \mu \mathrm{m})(n=13)$ (Fig. 1G). The telomere is twice as wide as the basimere and exhibits a group of bristles at the median portion and another four bristles dorsoapically $[90 \pm 4 \mu \mathrm{m}(84-100 \mu \mathrm{m}) ; n=13]$. The basimere is without bristles $[82 \pm 3 \mu \mathrm{m}(75-88 \mu \mathrm{m}) ; n=13]$. The phallosome is typical of the genus: it is articulated and both parts are roughly equal in size, at $331 \pm 9 \mu \mathrm{m}(317-346 \mu \mathrm{m})(n=12)$ in the proximal part, and $337 \pm 15 \mu \mathrm{m}(312-369 \mu \mathrm{m})(n=13)$ in the distal part. The angle between the parts measures $78 \pm 13^{\circ}\left(55-95^{\circ}\right)(n=13)$ (Fig. 1H).

Abdomen of the non-gravid female: the first and second spiracles are small and the rest are much larger. The spermatheca is conical (Fig. 1I).

Gravid female: located in the carapace of the host, perforating the osteoderms (Fig. 2A, B). The neosome is discoid, compressed anteroposteriorly, has an internal diameter of $2.4 \times 2.1 \mathrm{~mm}$, an external diameter of $2.6 \times 2.4 \mathrm{~mm}$, and thickness of $1 \mathrm{~mm}$ (Fig. 2C, D). The head and thorax are not invaginated in the abdomen. The caudal disc is wider than it is long.

Etymology. This new species is named according to the perforating habits of its females.

Tunga terasma Jordan, 1937

Specimens studied. Ex C.vellerosus, Santo Domingo, Córdoba Province $\left(30^{\circ} 28^{\prime} \mathrm{S}, 65^{\circ} 03^{\prime} \mathrm{W}\right.$ ) (4 July 2009), five males (MLP-XNT27, M1-M5); ex C. villosus (Desmarest, $1804)$, Coronel Suarez, Buenos Aires Province $\left(37^{\circ} 18^{\prime} 51^{\prime \prime} \mathrm{S}\right.$, $62^{\circ} 3^{\prime} 16^{\prime \prime} \mathrm{W}$ ) (12 January 2012), one male (MLP-XNT479, M3) and one non-gravid female (MLP-XNT479, F1).

Amended diagnosis. Hopkins and Rothschild (1953) observed that the male genitalia were similar to those in T. penetrans except in the shape of the manubrium (less straight and dorsal margin more convex). However, in four of five specimens studied, we observed that the dorsal margin of the 


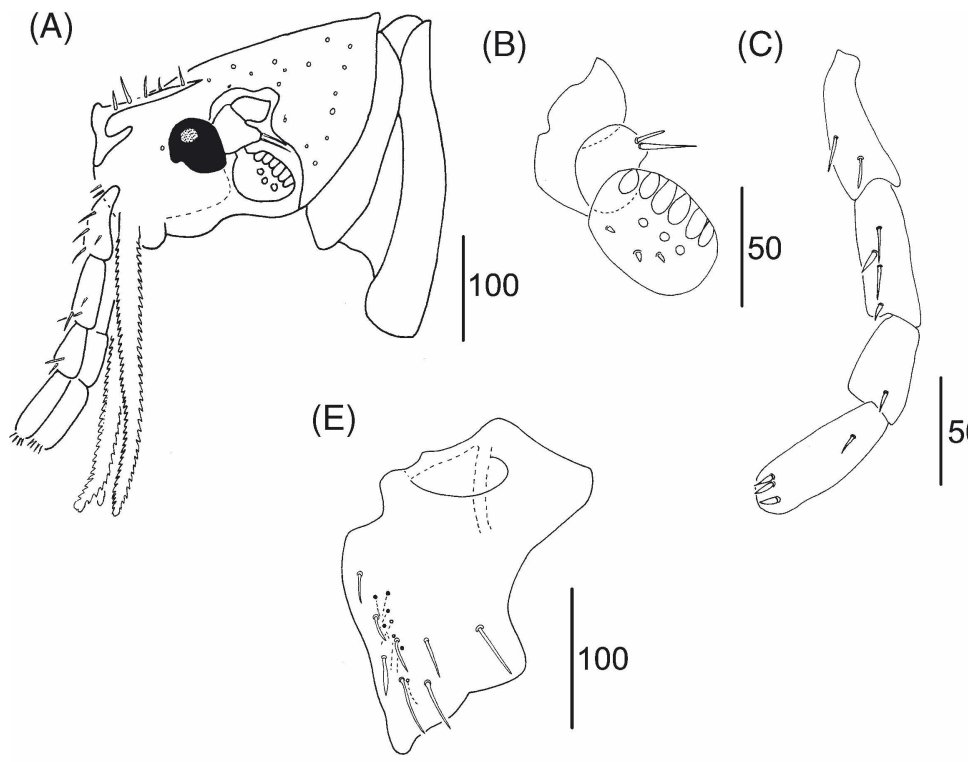

(G)

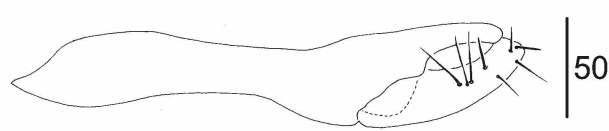

50
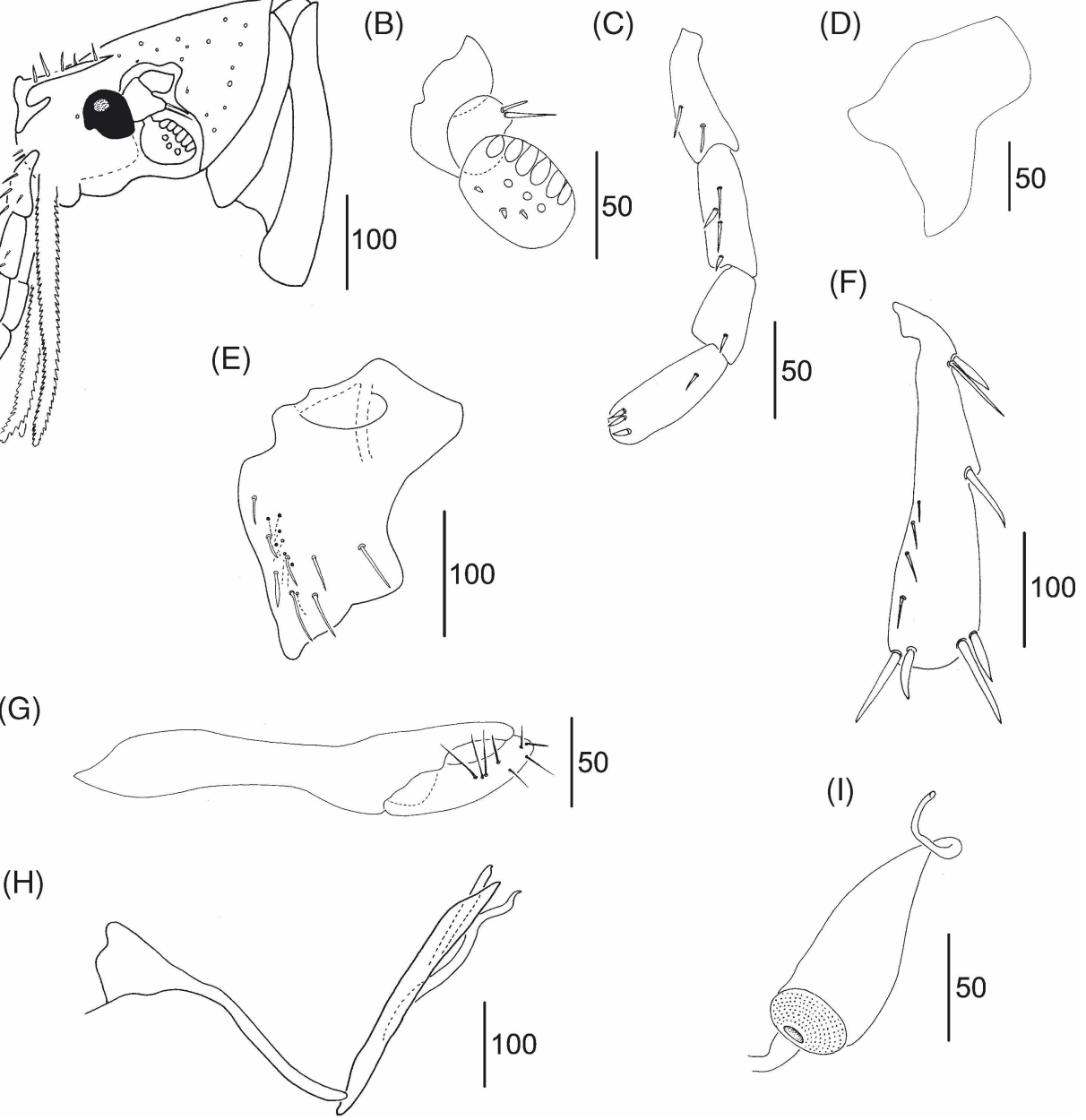

Fig. 1. Tunga perforans n. sp. (A) Male, head. (B) Female, antenna. (C) Maxillary palp. (D) Posterodorsal lobe of proepimeron. (E) Metacoxa. (F) Metatibia. (G) Segment IX in the male (clasper). (H) Phallosome. (I) Spermatheca of non-gravid female. Scale bars are in $\mu \mathrm{m}$.

manubrium is straight and the proximal end slightly pointed. This could be attributable to individual variation, as mentioned by Hopkins and Rothschild (1953). The specimens studied were slightly larger than males of T.penetrans, as indicated by Hopkins and Rothschild (1953), and the size of the spiracles is similar in both species, although the earlier authors found otherwise. Tunga terasma resembles T. trimamillata and $T$. penetrans because the pronotum and mesonotum are fused dorsally (penetrans group), the head is not invaginated within the abdomen in the hypertrophied female, and the eyes are large and pigmented. However, T. terasma differs from T. trimamillata and T. penetrans in the number of bristles in the metatibia, the maxillary palp with few thin bristles, the number of bristles on antennal segment II, the number of bristles on the anterior base of the maxilla, and in the shape of hypertrophied females.

Redescription. Head: five bristles are posterior to the frontal tubercle. In the internal preoral sclerotization, the anterior arm is slightly shorter than the posterior arm. The genal process extends to the antennal fossa, covering part of antennal segment III. The eye is large and pigmented, measuring $50 \pm 5 \mu \mathrm{m}$ $(42-55 \mu \mathrm{m})$ by $46 \pm 7 \mu \mathrm{m}(35-53 \mu \mathrm{m})(n=6)$ with a sinus in the internal margin; the greater diameter is similar to the distance to the dorsal margin of the head (Fig. 3A). Antennal segment II has two bristles. Antennal segment III has three placoids, without bristles (Fig. 3B). The maxillary palps have few bristles; segments I, II and IV are similar in length, and segment III measures two-thirds of the length of the other segments (Fig. 3C). The base of the maxilla has three small bristles.

Thorax: the pronotum is fused to the mesonotum; the pronotum and mesonotum show three and two bristles, respectively. The dorsal lobe of the proepimeron is rectangular.

Legs: the metacoxa shows eight bristles on the external side, restricted to the anterior margin, and a group of five to eight small and thin bristles on the internal side, restricted to the anterior margin (Fig. 3D). The third pair of legs shows four bristles in the anterior margin of the tibia (Fig. 3E).

Abdomen of the male: in segment IX the proximal end of the manubrium is pointed or slightly rounded, whereas the dorsal margin of the manubrium is straight (Fig. 3F). The telomere 

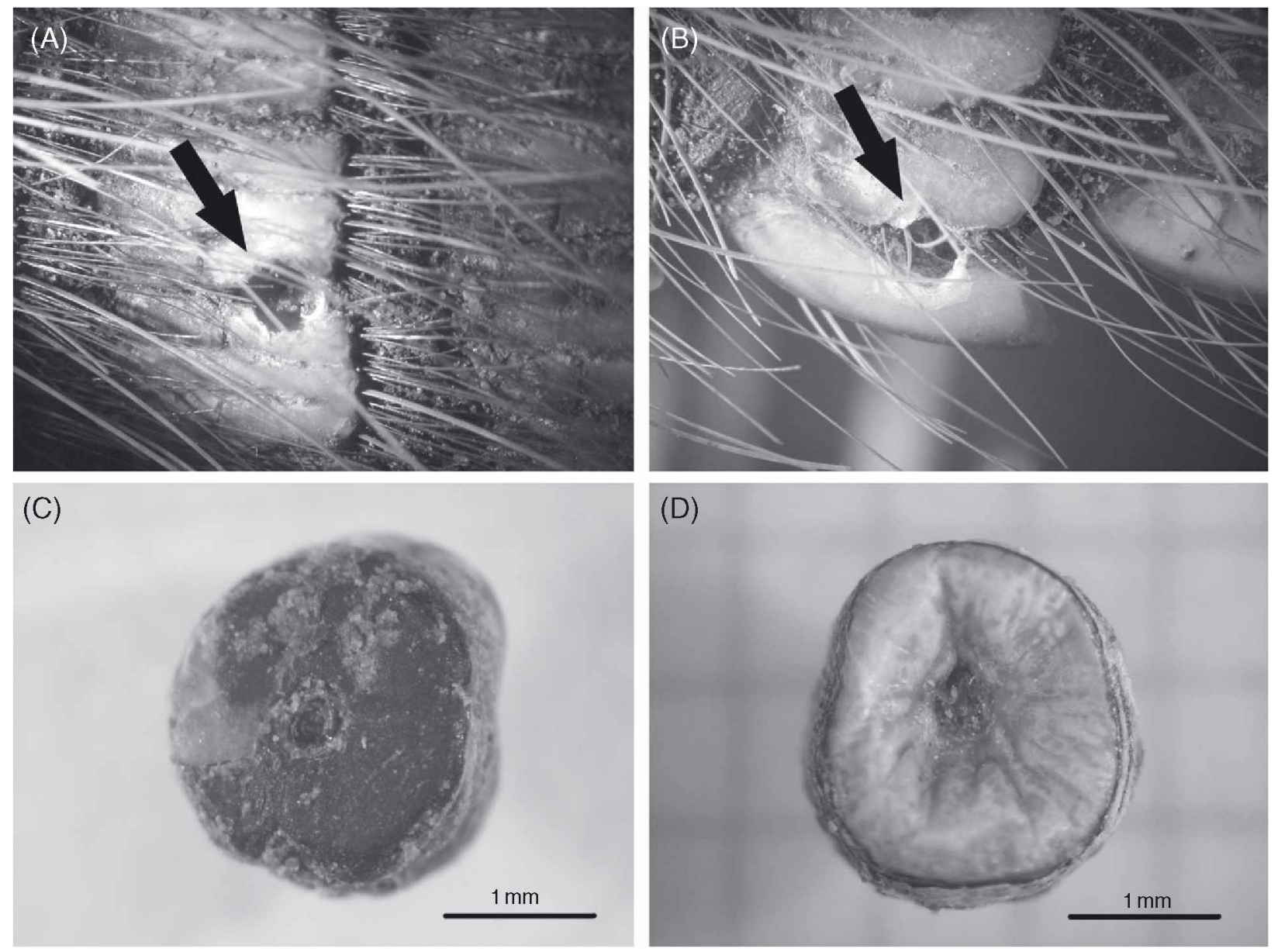

Fig. 2. Tunga perforans n. sp. (A, B) Perforated osteoderms; the arrow indicates the lesion. (C) Neosome, dorsal view. (D) Neosome, ventral view.

is wider than the basimere at the median and apical portions. Both the telomere and basimere show a group of three or four bristles at the apical portion. There is one large bristle at the dorsal margin of the telomere, near the base. Another four large bristles are seen at the base of the dorsal margin of the basimere. The phallosome is typical of the genus and is articulated, with the proximal part slightly longer than the distal part. The proximal part measures $346 \pm 16 \mu \mathrm{m}(331-370 \mu \mathrm{m})$ $(n=5)$ and the distal part measures $320 \pm 9 \mu \mathrm{m}(306-330 \mu \mathrm{m})$ $(n=5)$. The angle between the parts measures $84 \pm 9^{\circ}\left(70-90^{\circ}\right)$ $(n=4)$ (Fig. 3G).

Abdomen of the non-gravid female: the cribriform area is rather conspicuous, and the bulga and hilla are hardly visible. The bulga measures $90 \times 60 \mu \mathrm{m}$, and the hilla $40 \times 12 \mu \mathrm{m}$ (Fig. 3H).

\section{Geographical distribution}

The geographical distribution of the three species of Tunga that occur in Argentina is shown in Fig. 4. The localities where the carcasses with perforated osteoderms were found are also marked.
Key to species of the genus Tunga 'penetrans group' parasites of xenarthrans based on De Avelar et al. (2012)

1. The eye is without black pigment. The base of the maxilla shows only a micro-bristle. The neosome, with the head invaginated within the abdomen, measures $12-13 \mathrm{~mm}$ in length, $8 \mathrm{~mm}$ in width and $10 \mathrm{~mm}$ in height . .

T. travassosi Pinto and Dreyfus, 1927

The eye is pigmented. The base of the maxilla shows two or more bristles. In the neosome the head is not invaginated within the abdomen or is laterally visible $\ldots \ldots \ldots \ldots \ldots \ldots 2$

2. The eye is small, with a greatest diameter equivalent to slightly more than half the distance from the eye to the dorsal margin of the head. Antennal segment II has one bristle ......

T. bondari Wagner, 1932

The eye is large, with its greatest diameter nearly equal to the distance from the eye to the dorsal margin of the head. Antennal segment II has two or more bristles . . . . . . . . . . 3

3. Antennal segment II has four or five bristles. The maxillary palp has numerous bristles. The anteromedial surface of the posterior tibia is without bristles. The globular hypertrophied female measures $6 \mathrm{~mm}$ in length, $5 \mathrm{~mm}$ in width, and $5 \mathrm{~mm}$ in 

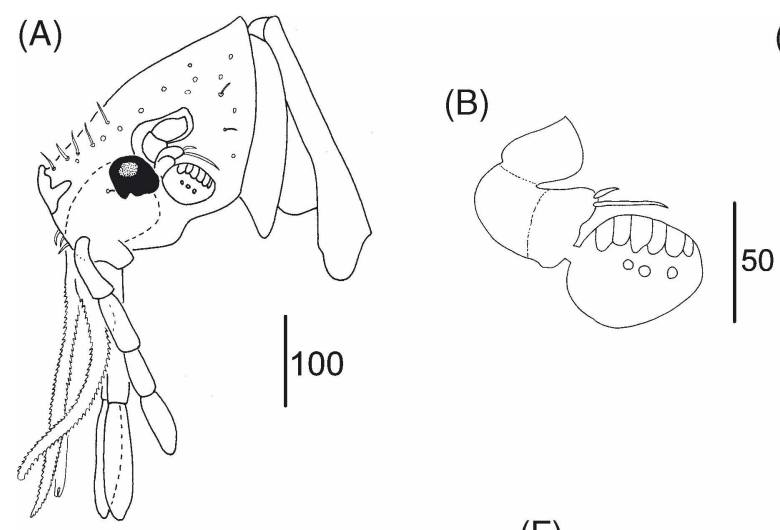

(C)
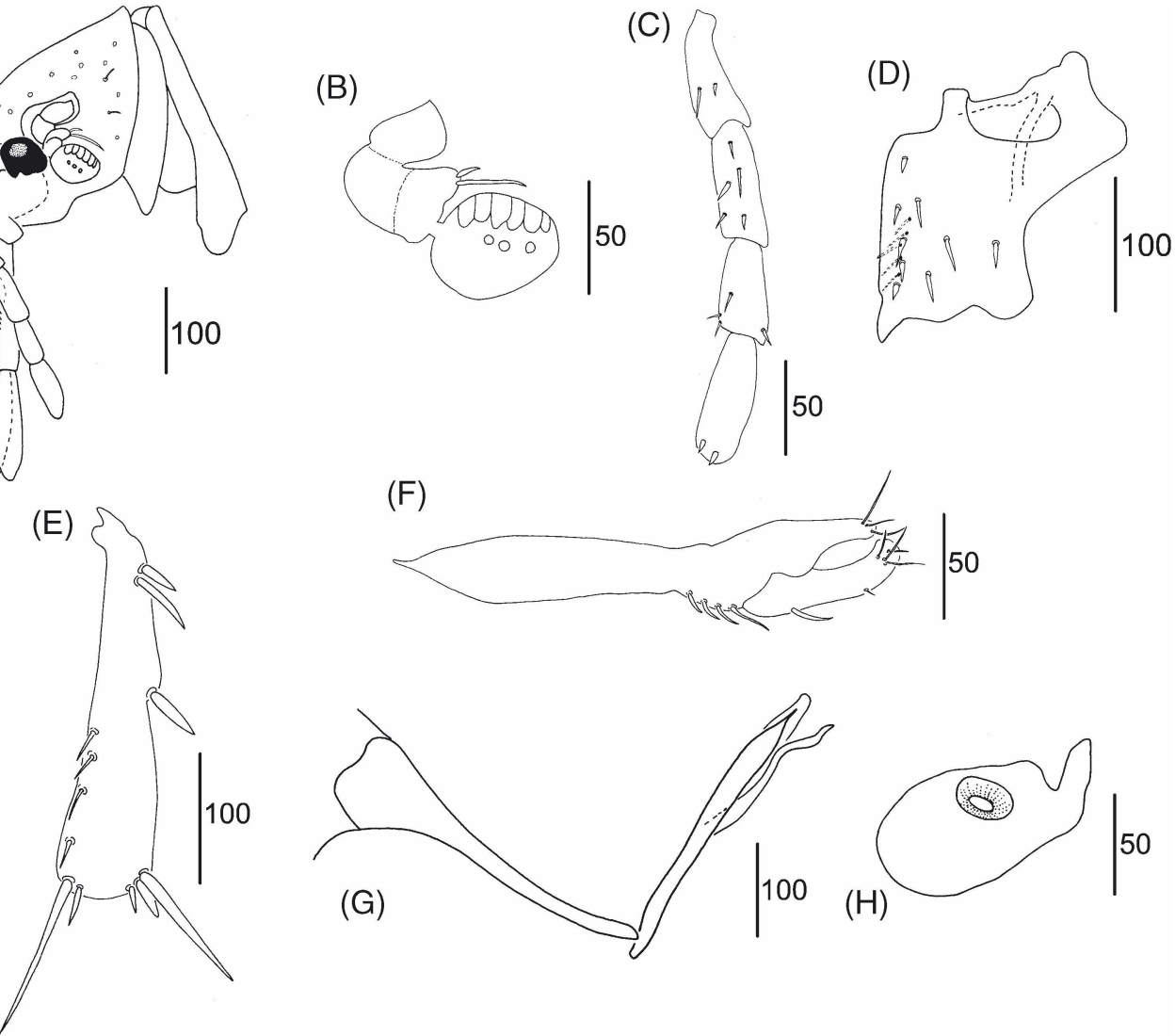

Fig. 3. Tunga terasma Jordan, 1937. (A) Male, head. (B) Antenna. (C) Maxillary palp. (D) Metacoxa. (E) Metatibia. (F) Segment IX in the male (clasper). (G) Phallosome. (H) Spermatheca of non-gravid female. Scale bars are in $\mu \mathrm{m}$.

height. The manubrium has a rounded proximal end rounded . . ........................ penetrans $(\mathbf{L} ., 1758)$

Antennal segment II has only two bristles. The maxillary palp has few bristles. The anteromedial surface of the posterior tibia has four bristles. The hypertrophied female is not globular. The manubrium shows a rounded or pointed proximal end rounded or pointed ......................

4. The hypertrophied female shows four prominent sub-cylindrical lobes, and measures $10 \mathrm{~mm}$ in length, $9 \mathrm{~mm}$ in width and $13 \mathrm{~mm}$ in height. The manubrium of the male shows straight dorsal and ventral margins, and a slightly rounded or pointed proximal end. The phallosome shows a slightly longer proximal part than distal part ........ T. terasma Jordan, 1937

The hypertrophied female is discoid and measures $2.4 \mathrm{~mm}$ in length, $1.0 \mathrm{~mm}$ in width and $2.1 \mathrm{~mm}$ in height. The manubrium of the male has an almost straight dorsal margin and convex ventral margin, and a sharp proximal end. Both parts of the phallosome are roughly equal in size ....... T. perforans $\mathrm{n}$. $\mathrm{sp}$.

\section{Discussion}

Tunga perforans $\mathrm{n}$. sp., described herein, is the only species of the genus in which gravid females are to be found inside the carapace of the host, perforating the osteoderms. The osteoderms or bony dermal scutes consist of compact bone and are overlaid by epidermal horny scales to form a protective dorsal cover (carapace) (Krmpotic etal., 2009). In addition, perforated carcasses of two specimens of Z. pichiy, one of C. villosus and one of Tolypeutes matacus (Cingulata: Dasypodidae) were found in Mendoza, La Pampa, Santa Cruz and San Juan Provinces, respectively (Fig. 4); we assume these are attributable to neosomes of species of Tunga4. The findings in the new species presented herein confirm the hypothesis of Whiting etal. (2008) with respect to the primary association between xenarthrans (dasypodids) and species of Tunga, and the new species demonstrates great adaptation to its host in its perforation of the osteoderm.

Tunga terasma was first described on the basis of a gravid female (Jordan, 1937). Previously, Fonseca (1936) had described the male based on specimens recovered from Euphractus sexcinctus (Cingulata: Dasypodidae) from Barrinha, São Paulo, Brazil, but he erroneously identified them as T. travassosi because both species possess the same number of bristles in antennal segment II and the first tarsomere. However, Fonseca (1936) noted that the eyes were pigmented, by contrast with the original description of T. travassosi (Pinto \& Dreyfus, 1927). Subsequently, Hopkins and Rothschild (1953) studied the same specimens and identified them as T.terasma. However, the descriptions of the male of T. terasma were poor. 


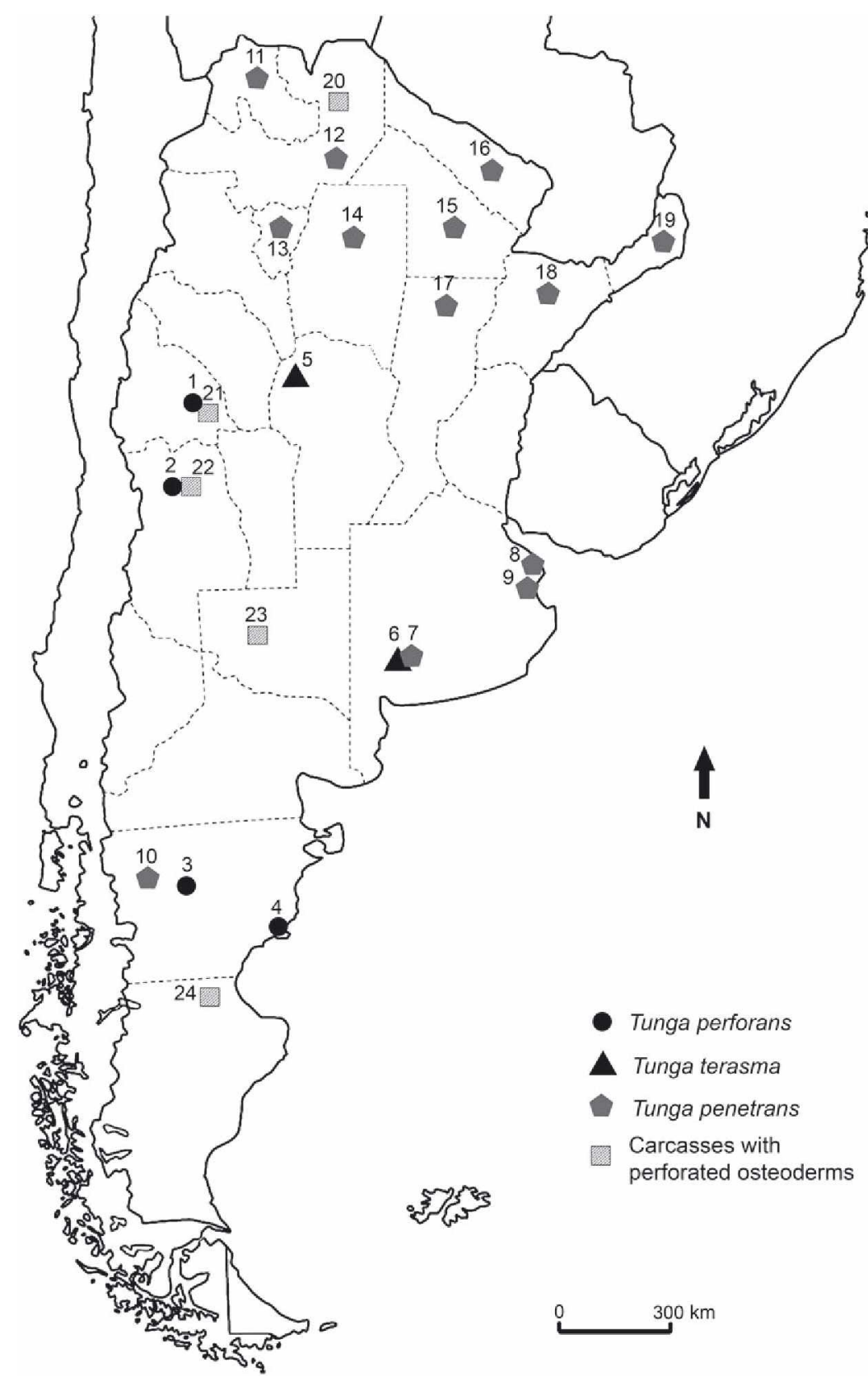

Fig. 4. Geographical distribution of species of the genus Tunga in Argentina (locality, province, host species and georeferences are indicated when known). Tunga perforans n. sp.: 1, Usno, San Juan Province $\left(30^{\circ} 33^{\prime} 39^{\prime \prime} \mathrm{S}, 67^{\circ} 32^{\prime} 15^{\prime \prime} \mathrm{W}\right)$, Chaetophractus vellerosus; 2, Luján de Cuyo, Mendoza Province $\left(33^{\circ} 01^{\prime} \mathrm{S}, 68^{\circ} 55^{\prime} \mathrm{W}\right)$, Zaedyus pichiy; 3, La Madrugada, Chubut Province ( $\left.43^{\circ} 37^{\prime} 40^{\prime \prime} \mathrm{S}, 68^{\circ} 57^{\prime} 08^{\prime \prime} \mathrm{W}\right)$, Z. pichiy; 4, Cabo Raso, Chubut Province $\left(44^{\circ} 20^{\prime} 22^{\prime \prime} \mathrm{S}, 65^{\circ} 14^{\prime} 59^{\prime \prime} \mathrm{W}\right)$, Z. pichiy. Tunga terasma Jordan 1937: 5, Santo Domingo, Córdoba Province ( $\left.30^{\circ} 28^{\prime} \mathrm{S}, 65^{\circ} 03^{\prime} \mathrm{W}\right)$, C. vellerosus; 6, Coronel Suarez, Buenos Aires Province $\left(37^{\circ} 18^{\prime} 51^{\prime \prime} \mathrm{S}, 62^{\circ} 3^{\prime} 16^{\prime \prime} \mathrm{W}\right)$, Chaetophractus villosus. Tunga penetrans L.: 7, Coronel Suarez, Buenos Aires Province $\left(37^{\circ} 18^{\prime} 51^{\prime \prime} \mathrm{S}, 62^{\circ} 3^{\prime} 16^{\prime \prime} \mathrm{W}\right)$, C. villosus (Ezquiaga, 2013); 8, Magdalena, Buenos Aires Province $\left(35^{\circ} 33^{\prime} \mathrm{S}, 57^{\circ} 14^{\prime} \mathrm{W}\right.$ ), C. villosus, C. vellerosus and Dasypus hybridus (Ezquiaga et al., 2008); 9, Castelli, Buenos Aires Province ( $36^{\circ} 01^{\prime} \mathrm{S}, 57^{\circ} 27^{\prime} \mathrm{W}$ ), C. villosus (Ezquiaga, 2013); 10, Tecka, Chubut Province $\left(43^{\circ} 24^{\prime} \mathrm{S}, 70^{\circ} 52^{\prime} \mathrm{W}\right.$ ), C. villosus (Ezquiaga, 2013); 11, Jujuy Province, pig, dog, human (González et al., 2003); 12, Salta Province, pig, dog, human (González et al., 2003); 13, Tucumán Province, pig, dog, human (González et al., 2003); 14 Santiago del Estero Province, pig, dog, human, Tolypeutes matacus (González etal., 2003; Ezquiaga, 2013); 15, Formosa Province, pig, dog, human (González etal., 2003); 16, Chaco Province, pig, dog, human (González etal., 2003); 17, Santa Fe Province, pig, dog, human (González etal., 2003); 18, Corrientes Province, pig, dog, human (González etal., 2003); 19, Misiones Province, pig, dog, human (González etal., 2003). Carcasses with perforated osteoderms: 20, Ruta Provincial 13, La Unión, Salta Province $\left(23^{\circ} 46^{\prime} 30^{\prime \prime} \mathrm{S}, 63^{\circ} 39^{\prime} 45^{\prime \prime} \mathrm{W}\right)$, T. matacus; 21 , Agua Cercada, Valle Fértil, San Juan Province $\left(30^{\circ} 48^{\prime} \mathrm{S}\right.$, $67^{\circ} 27^{\prime}$ W), T. matacus; 22, Mendoza Province, Z. pichiy (deposited at Colección Mastozoológica IADIZA, CONICET, Mendoza, Argentina); 23, La Pampa Province, Z. pichiy (unknown locality); 24, Piedra Parada, Santa Cruz Province ( $46^{\circ} 38^{\prime} 14^{\prime \prime} \mathrm{S}, 68^{\circ} 29^{\prime} 06^{\prime \prime}$ W), Z. pichiy. 
Antunes et al. (2006) extended the host range of T. terasma to include Dasypus novemcinctus L., 1758, but did not provide new morphological details. Herein, we present the first record of T. terasma in Argentina and extend its distribution approximately $2000 \mathrm{~km}$ to the southwest of the southern-most record known. Moreover, C. villosus and C. vellerosus are reported as new hosts for this species.

Members of Siphonaptera show co-evolutionary associations with their hosts. Hopkins and Rothschild (1953) represent the families in a phylogeny in which Tungidae and Pulicidae are grouped together. However, according to recent molecular studies, the genus Tunga is located at the base of the phylogeny of the Siphonaptera, as a sister clade of remainder fleas (Whiting et al., 2008). The xenarthrans hold a similar position in the phylogeny of mammals (Delsuc etal., 2004; Whiting etal., 2008). Therefore, the association with these basal mammals suggests that the origin and diversification of these parasites coincide with those of their mammalian hosts, and demonstrate a process of co-evolution, as postulated by De Avelar (2010).

In view of the fact that species of the genus Tunga can cause several disorders in xenarthrans and other mammal species, including humans (Pampiglione et al., 2009; De Avelar etal., 2013), the information provided in this study about the geographical and host distribution of two species of Tunga may be useful in epidemiological studies.

\section{Acknowledgements}

This work is part of the doctoral thesis of M. Cecilia Ezquiaga at the Universidad Nacional de La Plata. We thank Agustin M. Abba (MLP, UNLP, CONICET) and Daniel Udrizar Sauthier (CENPAT, CONICET) for identifying hosts, A.M. Abba for his help with field work, and Mariella Superina (IMBECU, CONICET), A. M. Abba, Luis G. Pagano and Juliana Sanchez (CEPAVE, CONICET), and Luis Rossi (UBA, CONICET) for providing specimens. We also thank Mariella Superina for translating a paper, M. Cristina Estivariz (CEPAVE, CONICET) for providing drawings, Luis Giambelluca (CEPAVE, CONICET) for providing photographs, and Néstor Cazzaniga (UNS) for his help with Latin. The study was supported by the Agencia Nacional de Investigaciones Científicas y Tecnológicas Argentina (PICT 2010-338 to ML), and Universidad Nacional de La Plata, Argentina (N627 and N618). PML is undertaking a research fellowship with the Conselho Nacional de Desenvolvimento Científico e Tecnológico (CNPq/Brazil). MCE and ML are members of the Consejo Nacional de Investigaciones Científicas y Técnicas (CONICET/Argentina).

\section{References}

Antunes, J.M.A.P., Demoner, L.d.C., Martins, I.V.F., Zanini, M.S., Deps, P.D. \& Pujol-Luz, J.R. (2006) Registro de Dasypus novemcinctus (Mammalia: Xenarthra) parasitado por Tunga terasma (Siphonaptera: Tungidae) em Alegre, Estado do Espírito Santo, Brasil. Revista Brasileira de Parasitologia Veterinária, 15, 206-207.
Audy, J.R., Radovsky, F.J. \& Vercammen-Grandjean, P.H. (1972) Neosomy: radical intrastadial metamorphosis associated with arthropod symbioses. Joumal of Medical Entomology, 9, 487-494.

De Avelar, D.M. (2010) Sistemática e análise cladística das espécies neotropicais do gểnero Tunga Jarocki, 1838 (Siphonaptera: Tungidae). $\mathrm{PhD}$ Thesis. Federal University of Minas Gerais, Belo Horizonte, $\mathrm{MG}$.

De Avelar, D.M., Linhares, A.X. \& Linardi, P.M. (2012) A new species of Tunga (Siphonaptera: Tungidae) from Brazil with a key to the adult species and neosomes. Joumal of Medical Entomology, 49, 23-28.

De Avelar, D.M., Facury Filho, E.J. \& Linardi, P.M. (2013) A new species of Tunga (Siphonaptera: Tungidae) parasitizing cattle from Brazil. Joumal of Medical Entomology, 50, 679-684.

Delsuc, F., Scally, M., Madsen, O. etal. (2002) Molecular phylogeny of living xenarthrans and the impact of character and taxon sampling on the placental tree rooting. Molecular Biology and Evolution, 19, $1656-1671$.

Delsuc, F., Vizcaíno, S.F. \& Douzery, E.J.P. (2004) Influence of tertiary paleoenvironmental changes on the diversification of South American mammals: a relaxed molecular clock study within xenarthrans. $B M C$ Evolutionary Biology, 4, 11.

Ezquiaga, M.C. (2013) Estudios parasitológicos en Dasypodidae (Mammalia, Xenarthra) de Argentina: el valor de la diversidad en la interpretación de las asociaciones parásito-hospedador-ambiente. $\mathrm{PhD}$ Thesis. Facultad de Ciencias Naturales y Museo, Universidad Nacional de La Plata, La Plata.

Ezquiaga, M.C., Lareschi, M., Abba, A.M. \& Navone, G.T. (2008) Nuevos registros de pulgas (Siphonaptera) parásitas de dasipódidos (Mammalia: Xenarthra) en el noreste de la provincia de Buenos Aires, Argentina. Mastozoología Neotropical, 15, 193-196.

Fonseca, F. (1936) Sobre o macho de Tunga travassosi Pinto et Dreyfus, 1927, e o parasitismo de Euphractes sexcinctus L. por Tunga penetrans (L., 1758) (Siph. Tungidae). Revista de Entomologia, 6, 421-424.

González, A., de Villalobos, C. \& Ranalletta, M.A. (2003) Tungiosis. Ectoparasitosis Humanas (ed. by A. González, C. de Villalobos \& M.A. Ranalletta), pp. 284-301. Ediciones Científicas Americanas, Buenos Aires.

Heukelbach, J., Costa, A.M.L., Wilcke, T., Mencke, N. \& Feldmeier, H. (2004) The animal reservoir of Tunga penetrans in severely affected communities of north-east Brazil. Medical and Veterinary Entomology, 18, 329-335.

Hopkins, G.H. \& Rothschild, M. (1953) An Illustrated Catalogue of the Rothschild Collection of Fleas (Siphonaptera) in the British Museum of Natural History. I. Tungidae and Pulicidae. British Museum of Natural History, London.

Jordan, K. (1937) Two new fleas from South America. Novitates Zoologicae, 40, 307-310.

Krmpotic, C.M., Ciancio, M.R., Barbeito, C., Mario, R.C. \& Carlini, A.A. (2009) Osteoderm morphology in recent and fossil euphractine xenarthrans. Acta Zoologica (Stockholm), 90, 339-351.

Lareschi, M., González, A. \& de Villalobos, C. (2005) Siphonaptera-Pulgas. Artrópodos de Interés Médico en Argentina, Serie Enfermedades Transmisibles, Publicación Monográfica No. 6 (ed. by O.D. Salomón), pp. 85-89. Fundación Mundo Sano, Buenos Aires.

Linardi, P.M. \& De Avelar, D.M. (2014) Neosomes of tungid fleas on wild and domestic animals. Parasitology Research, 113, 3517-3533.

Linardi, P.M. \& Guimarāes, L.R. (2000) Sifonápteros do Brasil. Ed. MZUSP, FAPESP, São Paulo, SP. 
Marshall, A. (1981) The Ecology of Ectoparasitic Insects. Academic Press, London.

Pampiglione, S., Fioravanti, M.L., Gustinelli, A., Onore, G., Mantovani, B., Luchetti, A. \& Trentini, M. (2009) Sand flea (Tunga spp.) infections in humans and domestic animals: state of the art. Medical and Veterinary Entomology, 23, 172-186.

Pinto, C. \& Dreyfus, A. (1927) Tunga travassosi n. sp., parasita de Tatusia novemcinctus do Brasil. Boletim Biologico, 9, 174-178.

Smit, F.G.A.M. (1962) A new sand-flea from Ecuador. Entomologist, 95, 89-93.
Smit, F.G.A.M. (1987) An Illustrated Catalogue of the Rothschild Collection of Fleas (Siphonaptera) in the British Museum (Natural History), Vol. VII. Malacopsylloidea. Oxford University Press, Oxford. Whiting, M.F., Whiting, A.S., Hastriter, M.W. \& Dittmar, K. (2008) A molecular phylogeny of fleas (Insecta: Siphonaptera): origins and host associations. Cladistics, 24, 1-31.

Accepted 4 November 2014

First published online 29 January 2015 